This item was submitted to Loughborough's Research Repository by the author.

Items in Figshare are protected by copyright, with all rights reserved, unless otherwise indicated.

\title{
Catastrophic drought in the Afro-Asian monsoon region during Heinrich Event 1
}

PLEASE CITE THE PUBLISHED VERSION

http://dx.doi.org/10.1126/science.1198322

PUBLISHER

American Association of Advancement of Science (@ The author)

VERSION

AM (Accepted Manuscript)

LICENCE

CC BY-NC-ND 4.0

REPOSITORY RECORD

Stager, Curt J., David B. Ryves, Brian M. Chase, and Francesco S.R. Pausata. 2019. "Catastrophic Drought in the Afro-asian Monsoon Region During Heinrich Event 1”. figshare. https://hdl.handle.net/2134/8695. 
This item was submitted to Loughborough's Institutional Repository (https://dspace.lboro.ac.uk/) by the author and is made available under the following Creative Commons Licence conditions.

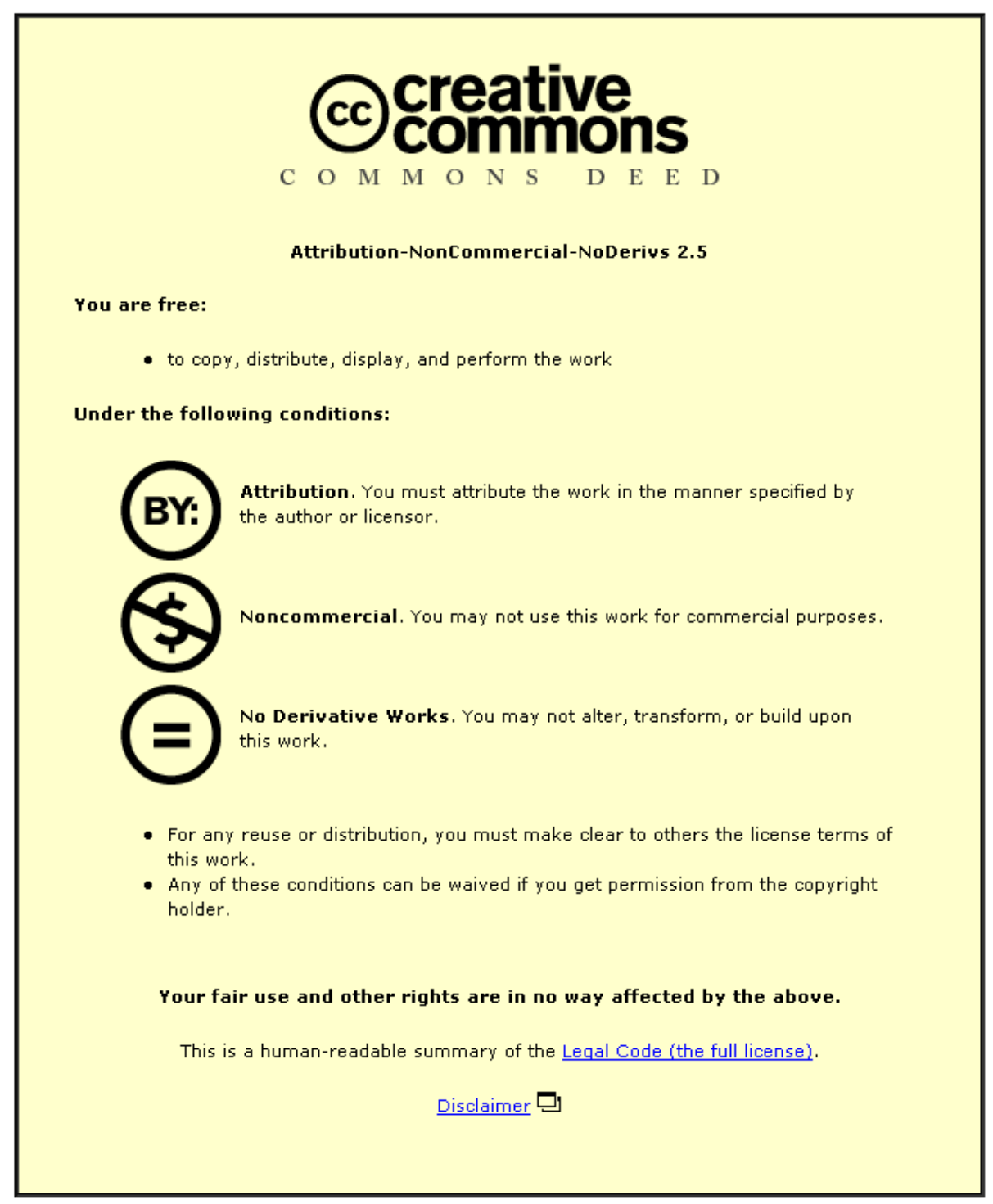

For the full text of this licence, please go to: http://creativecommons.org/licenses/by-nc-nd/2.5/ 
Catastrophic drought in the Afro-Asian monsoon region during Heinrich Event 1.

SCIENCE MANUSCRIPT\# 1198322, accepted Feb 2011

J. Curt Stager ${ }^{1,2}$, David B. Ryves ${ }^{3}$, Brian M. Chase ${ }^{4,5}$, and Francesco S.R. Pausata ${ }^{6}$.

1. Natural Sciences, Paul Smith's College, Paul Smiths, NY 12970 USA, (cstager@paulsmiths.edu)

2. Climate Change Institute, University of Maine, Orono, ME 04469 USA

3. Centre for Hydrological and Ecosystem Science, Department of Geography, Loughborough University, Loughborough, LE11 3TU, UK (D.B.Ryves@lboro.ac.uk)

4. Institut des Sciences de l'Evolution de Montpellier, UMR 5554 Université Montpellier

2, Bat.22, CC061, Place Eugène Bataillon 34095 Montpellier CEDEX 5, France.

(Brian.Chase@univ-montp2.fr)

5. Department of Archaeology, History, Cultural Studies and Religion, University of Bergen, 5020 Bergen, Norway (Brian.Chase@ahkr.uib.no)

6. Geophysical Institute, University of Bergen, Allégaten 70, 5007 Bergen, Norway. (francesco.pausata@uni.no)

\begin{abstract}
Between 18,000 and 15,000 years ago, large amounts of ice and meltwater entered the North Atlantic during Heinrich Stadial 1. This caused substantial regional cooling, but major climatic impacts also occurred in the tropics. Here we demonstrate that the height of this stadial, ca. 17-16,000 years ago ("Heinrich Event 1 "), coincided with one of the most extreme and widespread megadroughts of the last 50,000 years or more in the Afro-Asian monsoon region, with potentially serious consequences for Paleolithic cultures. Late Quaternary tropical drying commonly is attributed to southward drift of the Intertropical Convergence Zone, but the broad geographic range of the H1 Megadrought suggests that severe, systemic weakening of Afro-Asian rainfall systems also occurred, probably in response to sea surface cooling.
\end{abstract}


Meridional repositioning of the Intertropical Convergence Zone (ITCZ), the primary source of rainfall in most of the tropics, is thought to have been a major source of hydrological variability during the late Quaternary (1-4). For example, ice sheet expansion forced the mean latitudinal position of the ITCZ southward along with other atmospheric circulation systems in the northern hemisphere during the Last Glacial Maximum (3), and abrupt North Atlantic cooling during deglacial melting and ice-rafting episodes such as Heinrich Stadial 1 (HS-1), along with associated reductions of marine meridional overturning circulation (MOC), is also thought to have had a similar effect on rain belts associated with the $\operatorname{ITCZ}(1,3,4)$. Some model simulations of northern hemisphere climatic changes associated with HS-1 indicate a southward drift of up to 10 latitudinal degrees (2). Most of northern Africa became unusually dry around 17-16 thousand calendar years ago (ka) during the HS-1 ice-rafting peak of Heinrich Event 1 (H1), including the Sahara and Sahel (5), Ethiopia (6), and the Red Sea region (7), as did most of southern Asia (8-11; Figs. 1 and 2). Affecting most of the northern Old World tropics, this arid episode brought some of the most severe drought conditions of the last 50,000 years or more to many of the terrestrial sites that cover such long time periods in detail (Fig. 2; supporting online text).

Under such circumstances, a more southerly-positioned ITCZ would presumably deliver less rain to the northern tropics while causing little change near the equator and wetter conditions in the southern tropics. However, a relative scarcity of high-resolution paleoclimate records from much of the inner and southern tropics has left this commonly cited hypothesis sparsely tested, particularly in Africa. This, in turn, has also limited understanding of the effects of major events such as $\mathrm{H} 1$ on global climates. In this paper, we present a collection of new and recently published records from Africa that register severe aridity in the equatorial and southern tropics ca. 17-16 ka, thereby showing that the H1 Megadrought extended far beyond the northern tropics and was therefore one of the most intense and far-reaching dry periods in the history of anatomically modern humans. Together, these records also show that southward drift of the ITCZ cannot have been the only cause of low-latitude drought during H1, and instead suggest that a significant weakening of tropical rainfall systems also occurred.

If the ITCZ did shift several degrees southwards over Africa and Asia during H1, it should still have delivered rains to equatorial regions once or twice annually unless the latitudinal shift was unrealistically large, on the order of 20 degrees or more. However, extreme equatorial drying centered on 17-16 ka also occurred in northern Tanzania (12; this study), Ghana (13) and the Niger-Sanaga and Congo watersheds (14, 15; Fig. 1) as well as in Borneo on the opposite side of the Indian Ocean (16) much as it did in the more northerly reaches of the tropics from the Mediterranean Basin to the western Pacific (Figs. 1-3; supporting online text).

A dramatic event associated with these equatorial changes was the desiccation of Lake Victoria, East Africa (Fig. 1), which today is the world's largest tropical lake. With rainfall over the watershed possibly reduced to less than a quarter of its present amount (7), the lake dried out twice between 18 and $15 \mathrm{ka}$, though the timing of the two low stands has previously been unclear (supporting online text). We present here radiocarbon 
dates and diatom records from two cores which show that the first of these low stands occurred ca. 17-16 ka (Fig. 3D; 17). The disappearance of Lake Victoria would have had severe ecological impacts on regional ecosystems and cultures from eastern equatorial Africa to the Mediterranean coast. It is the largest water source for the Nile River during seasonal low flood stages, and Lake Tana, Ethiopia, is the primary source of the Nile's seasonal high floods; both lakes dried out completely at that time (6).

In addition, an analysis of diatom assemblages in a core from Lake Tanganyika, Tanzania (17), supports geochemical evidence (18) that a major low stand occurred ca. 17-16 ka there, as well (Figs. 2D and 3F). We therefore link the synchronous regressions at Lakes Victoria and Tanganyika to the H1 ice-rafting peak that occurred ca. 17-16 ka during the longer Heinrich Stadial period in the North Atlantic $(3,19)$, while recognizing that the ages assigned to these events are subject to the limitations of radiocarbon dating, variable carbon reservoir effects, and bioturbation. Together, these equatorial records demonstrate that a simple southward shift of the ITCZ cannot have been the only climatic mechanism to affect tropical rainfall significantly during $\mathrm{H} 1$.

The occurrence of major droughts to the south of equatorial Africa during H1 even more clearly requires a mechanism other than southward drift of the ITCZ over the continent, which would be expected to make those regions wetter as the north became drier (Figs. 13). These sites included Lake Malawi (20), the Zambezi and Limpopo watersheds (21, 22), and other locations in southeastern Africa (Fig. 1; supporting online text).

In contrast, parts of southwestern Africa became wetter during H1 (cf. 23), but hydrology there can also be influenced by rainfall systems other than the ITCZ, such as winter storms carried on the austral mid-latitude westerlies. The complexity of the interactions between subtropical and Southern Ocean dynamics is highlighted in a stable isotope record from the Western Cape, where changes in sea surface temperatures (SST) as a result of variability in MOC and/or the Agulhas Current caused progressively wetter conditions in that region across H1 (24; Fig. 1). Further north, in the Kalahari, Burrough et al. (25) favored an easterly ITCZ rainfall source for an enlarged paleolake Makgadikgadi, proposed largely on the basis of sandy deposits on western shorelines, but droughts to the north and east, along with the possibility of distant runoff sources in addition to deflation and downwind sediment deposition during dry seasons, suggest an alternative interpretation, as well. Wetter conditions in the Kalahari at that time might also be consistent with a northward extension of winter rains, which could have brought increased precipitation to Namibia during H1 (26). Wetter conditions could also reflect enhanced runoff from high stratiform clouds and fogs in the Angola highlands related to cooling along the Benguela coast (27), rather than a southward shift of the ITCZ alone.

Hydrological conditions in the New World tropics are difficult to interpret in this context. Extreme aridity is registered in cores from the Cariaco Basin ca. 17-16 ka (1), and regional increases in precipitation occurred farther south in the tropical Andes and parts of Amazonia during $\mathrm{H} 1(1,3)$. This pattern appears to be consistent with a southward shift of the mean position of the ITCZ, though it is not found universally (supporting online text). Most importantly in the context of this study, however, the development of 
wet conditions in numerous neotropical sites suggests that the proposed general weakening of rainfall systems over Africa did not occur in South America, and that it apparently represented regional, rather than uniformly global changes in tropical atmospheric circulation.

General circulation models (GCMs) often have more difficulty in simulating precipitation than temperature, and GCM reconstructions of tropical rainfall are less well supported by historical instrumental weather data than those that focus on the northern temperate zone. Furthermore, to our knowledge no modeling studies of deglacial climates have as yet been constrained by a detailed array of paleohydrological records spanning most of the African continent. Our findings are therefore useful for evaluating model reconstructions of past climates in Africa and of the global effects of H1, and we summarize several GCM simulations here in order to illustrate the difficulty of reconciling current GCM output with paleoclimatic reconstructions. For example, while Mulitza et al. (5) correctly simulated Sahel aridity in response to weakened MOC that was typical of the HS-1 interval, the model shows wetting over much of central Africa that is inconsistent with the data available. Kageyama et al. (2) correctly inferred Indian aridity but did not fully extend it to equatorial and southern Africa, while simulations by Thomas et al. (4), which identified wetting in the Angola-Kalahari region, did not completely capture the extreme aridity that occurred in much of the rest of the continent.

Given the mismatches between recent GCM simulations and paleoclimate records of $\mathrm{H} 1$ in the Afro-Asian region, we suggest several possible causal mechanisms here. The occurrence of droughts throughout tropical Africa indicates that they most likely involved a reduction of convection and/or moisture content in the ITCZ, with or without a concurrent shift in its position. Surface warming in Lake Tanganyika during the driest interval of a 60,000 year sediment record (18; Fig. 2D), for example, might indicate reduced evaporative cooling and upwelling linked to a weakening of atmospheric circulation over East Africa during H1; a severe reduction of summer monsoon wind activity was also registered in the Arabian Sea then (8). It has been hypothesized elsewhere that the southern limb of the tropical Hadley circulation system weakened during the longer HS-1 interval (3), which would also be consistent with the paleoclimate records indicating drought in equatorial and southern Africa.

Cooler sea surface temperatures (SST) in the SE Atlantic and Indian Oceans also represent plausible mechanisms for the inferred reductions of tropical rainfall because lower SSTs would tend to reduce the evaporative moisture content of the ITCZ. Cooling along the West African coast likely contributed to summer monsoon failure there $(5,27)$, and low SSTs in the western Indian Ocean (28) may likewise have contributed to aridity over eastern Africa. Conditions elsewhere along the margins of the Indian Ocean basin during H1 probably made SST cooling particularly widespread there, as well. Stronger upwelling in the Southern Ocean may have cooled the southern margins of the Indian Ocean (29) and deflected cold, eastward-flowing water masses equatorward. Additionally, at that time much of today's warm Pacific through-flow was blocked by landmasses in the Indonesian region due to a sea level low-stand, thereby reducing Pacific heat inputs into the area, and reduced SSTs in much of the northern Indian Ocean 
$(8,21)$, might have resulted from cooling by strong, south-trending winter monsoon winds over landmasses that were concurrently chilled by conditions upwind in the Mediterranean and North Atlantic (3).

More than half of all humanity is strongly influenced by Afro-Asian rainfall systems today, and anatomically modern humans evolved under their influence, yet the mechanisms behind precipitation variability in these regions remain relatively poorly understood and difficult to model. Furthermore, the unusual intensity and exceptionally broad geographic distribution of the H1 Megadrought have not yet been widely recognized. The records presented here show that it was one of the most intense and extensive tropical dry periods of the last 50,000 years or more (Figs. 1, 2), spanning roughly 60 latitudinal degrees, virtually all of southern Asia, and most of the African continent, and that it must have involved a systemic, as yet unexplained weakening of regional rainfall systems in addition to southward displacement of the ITCZ. Whatever its exact cause, such a catastrophic drought would have had powerful effects on Paleolithic cultures. For example, the desiccations of Lakes Tana and Victoria reorganized the distribution of wet and arid-environment resources in the region, Middle Eastern drying would have hindered overland migrations into or out of Africa, and aridity around this time period likely contributed to major reductions in human populations in southern Asia (30). 


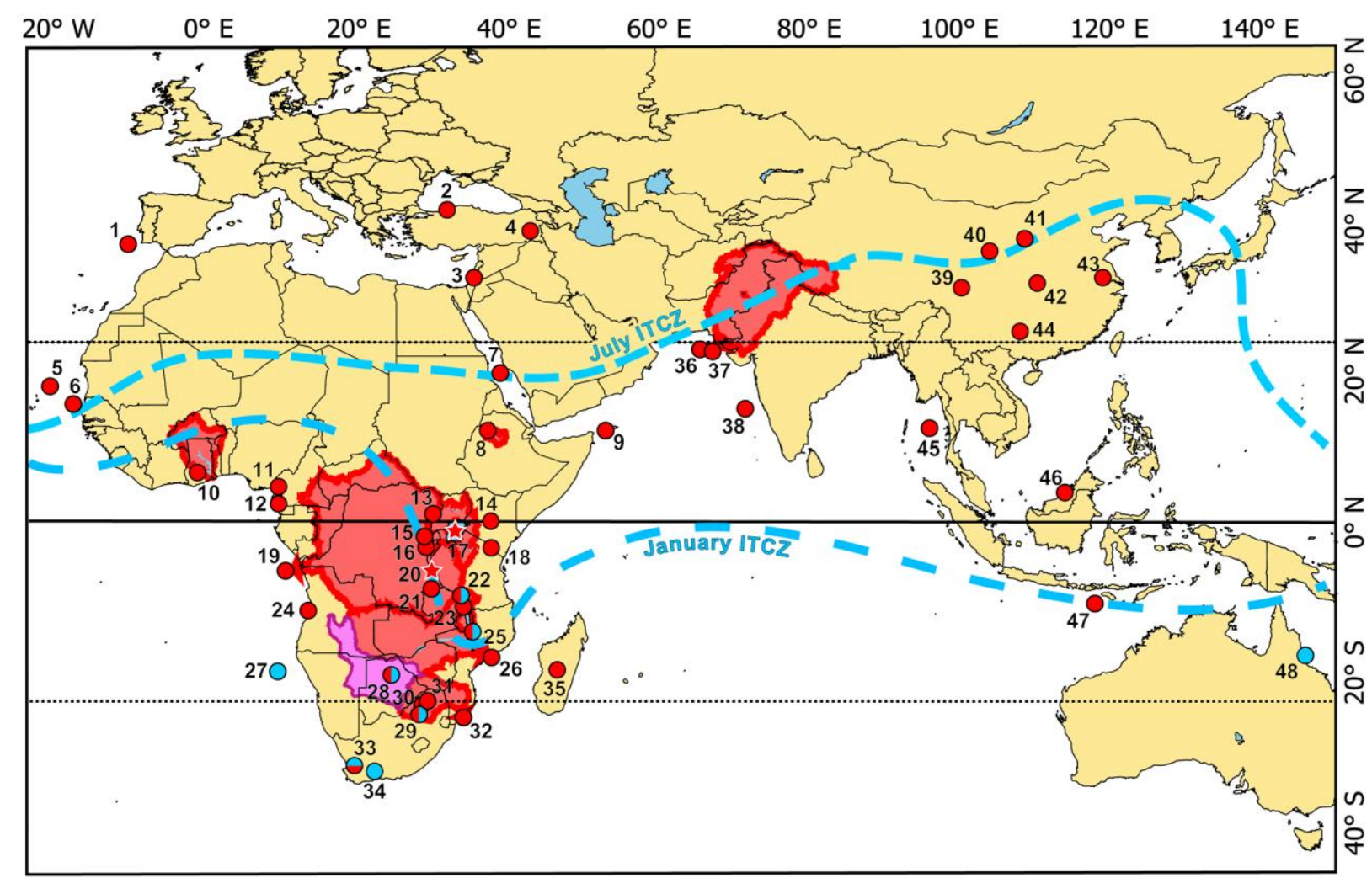

Figure 1: Site map of records showing hydrological conditions during the 17-16 ka interval (details listed in Table 3, supporting online material). Red dots: reduced precipitation-evaporation. Blue dots: increased precipitation-evaporation. Vertically divided red/blue dots indicate signals of uncertain climatic significance. Horizontally divided dots indicate a trend of progressively moister climates across HS-1. Note that only the specific study sites and some of the major watersheds are indicated; the full geographic area affected by the H1 Megadrought is not completely colored in. For example, records from marine sites 5 and 6 reflect climatic conditions in much of northwestern Africa. Purple shading in the Kalahari region indicates wetter conditions of uncertain origin, timing, and/or geographic extent. 


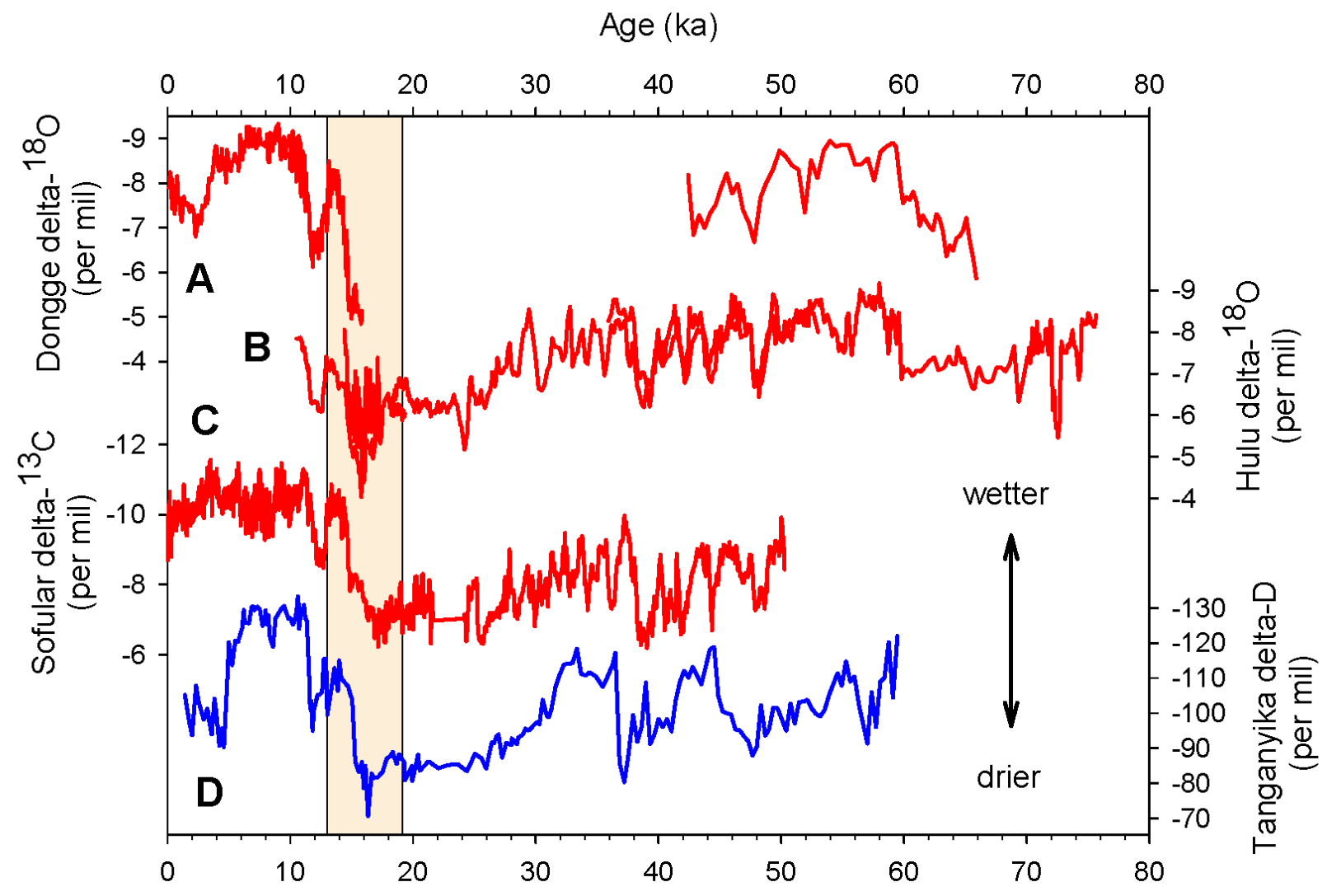

Figure 2. Examples of terrestrial paleohydrological records in which the $\mathrm{H} 1$ signal was among the most intense of the last $50 \mathrm{kyr}$ or more. (A) Dongge Cave, China, speleothem $\delta^{18} \mathrm{O}(9),(\mathbf{B})$ Hulu Cave, China, speleothem $\delta^{18} \mathrm{O}$, composite time series (10), (C) Sofular Cave, Turkey, speleothem $\delta^{18} \mathrm{O}(11)$, (D) Lake Tanganyika, East Africa, $\delta \mathrm{D}(18)$. Although these records do not mean that all intervening sites necessarily experienced uniquely intense drought during $\mathrm{H} 1$, they do establish that the pattern was widely distributed, spanning southern Asia and extending south of the equator in East Africa. Colored column represents the 19-13 ka time period illustrated in Figure 3. 


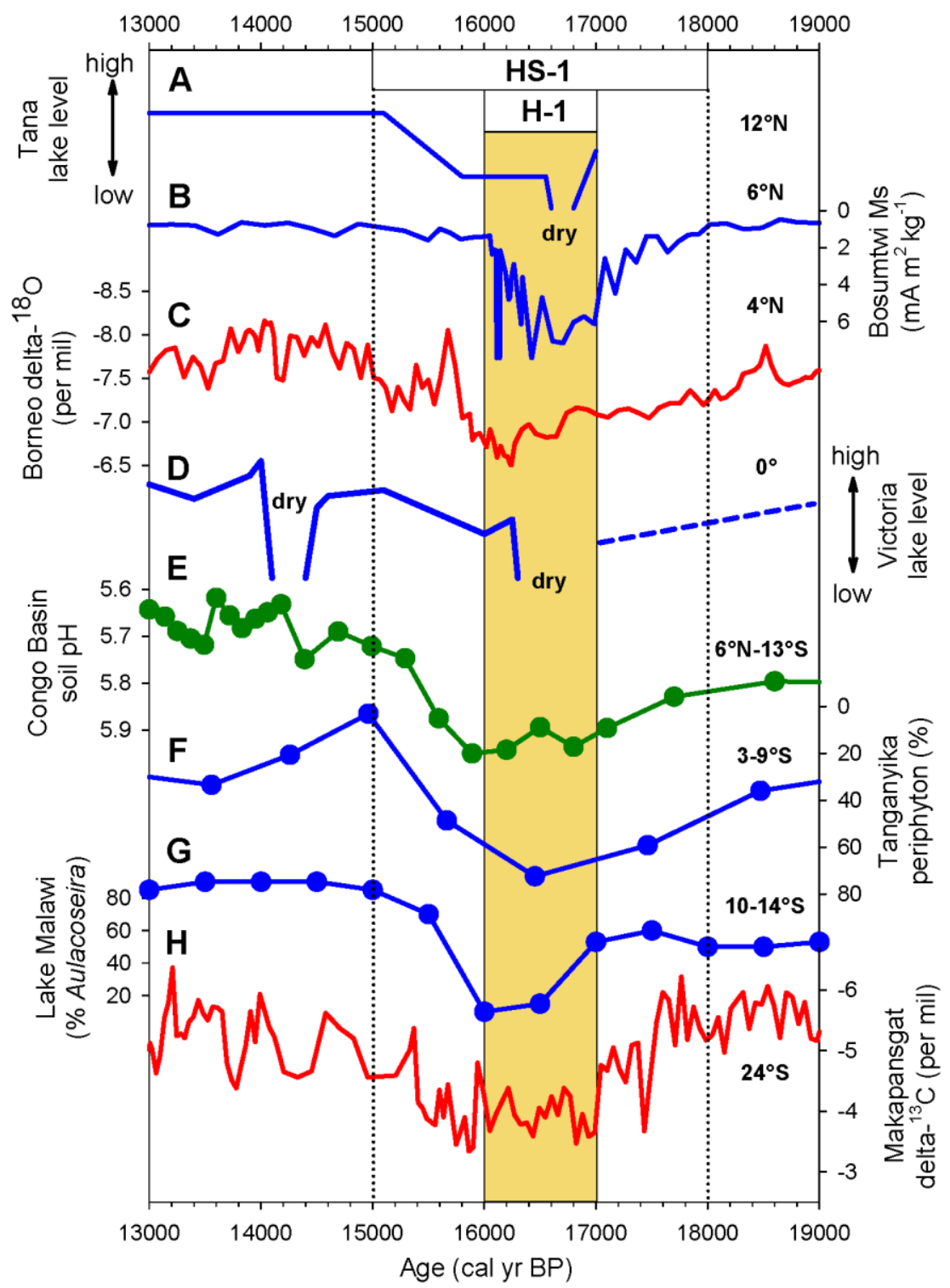

Figure 3. Paleoclimatic records of the 19-13 ka interval from Africa and Borneo, ordered from north to south (latitude on right for each site). (A) Lake Tana, Ethiopia, relative level, no units (after 6), (B) Lake Bosumtwi magnetic mineral concentration (13), (C) Borneo speleothem, $\delta^{18} \mathrm{O}$ series $(16)$, (D) Lake Victoria relative lake level (this study), (E) Congo basin soil pH (15), (F) Lake Tanganyika \% periphytic diatoms (inverted; this study), (G) Lake Malawi Aulacoseira nyassensis with lower \% indicating less windy and/or drier conditions (after 20), (H) Stalagmite T7 from Cold Air Cave, $\delta^{13} \mathrm{C}$ series (31). Brown bar: approximate H1 interval. Dotted lines bracket approximate HS-1 interval. All time series are arranged with drying trends oriented downwards. 


\section{References and notes}

1. L. C. Peterson, G. H. Haug, K. A. Hughen, U. Röhl, Science 290, 1947 (2000).

2. M. Kageyama et al., Clim. Past 5, 551 (2009).

3. G. H. Denton et al., Science 328, 1652 (2010).

4. D. S. G. Thomas, R. Bailey, P. A. Shaw, J. A. Duncan, J. S. Singarayer, Quaternary Science Reviews 28, 526 (2009).

5. S. Mulitza et al., Paleoceanography 23, PA4206 (2008).

6. H. F. Lamb et al., Quaternary Science Reviews 26, 287 (2007).

7. W. S. Broecker, D. Peteet, I. Hajdas, J. Lin, E. Clark, Quaternary Research 50, 12 (1998).

8. H. Rashid, B. P. Flower, R. Z. Poore, T. M. Quinn, Quaternary Science Reviews 26, 2586 (2007).

9. D. Yuan, et al., Science 304, 575 (2004).

10. Y. J. Wang et al., Science 294, 2345 (2001).

11. D. Fleitmann et al., Geophysical Research Letters 36, L19707 (2008).

12. D. Verschuren et al., Nature 462, 637 (2009).

13. J. A. Peck et al., Palaeogeography, Palaeoclimatology, Palaeoecology 215, 37 (2004).

14. S. Weldeab, D. W. Lea, R. R. Schneider, N. Andersen, Science 316, 1303 (2007).

15. J. W. H. Weijers, E. Schefuß, S. Schouten, J. S. S. Damsté, Science 315, 1701 (2007).

16. J. W. Partin, K. M. Cobb, J. F. Adkins, B. Clark, D. P. Fernandez, Nature 449, 452 (2007).

17. Materials and methods are available as supporting material on Science Online.

18. J. E. Tierney et al., Science 322, 252 (2008).

19. E. Bard, F. Rostek, J.-L. Turon, S. Gendreau, Science 289, 1321 (2000). 
20. F. Gasse, P. Barker, T. C. Johnson, in The East African Great Lakes: Limnology, Palaeoclimatology and Biodiversity, E. O. Odada, D. O. Olago, Eds. (Kluwer Academic Publishers, Dordrecht, 2002), pp. 393-414.

21. L. Dupont, T. Caley, B. Malaize, J. Girardeau, Geophysical Research Abstracts 12, (2010).

22. Y. Wang, T. Larsen, N. Andersen, T. Blanz, R. Schneider, Geophysical Research Abstracts 12, (2010).

23. B. M. Chase, M. E. Meadows, Earth-Science Reviews 84, 103 (2007).

24. B. M. Chase et al., Geology 39, 19 (2011).

25. S. L. Burrough, D. S. G. Thomas, J. S. Singarayer, Earth-Science Reviews 96, 313 (2009).

26. J.-B. W. Stuut et al., Marine Geology 180, 221 (2002).

27. L. M. Dupont, H. Behling, J. H. Kim, Clim. Past 4, 107 (2008).

28. E. Bard, F. Rostek, C. Sonzogni, Nature 385, 707 (1997).

29. R. F. Anderson et al., Science 323, 1443 (2009).

30. S. Kumar et al., BMC Evolutionary Biology 8, 230 (2008).

31. K. Holmgren et al., Quaternary Science Reviews 22, 2311 (2003).

32. Acknowledgements: This study was supported by National Science Foundation grant EAR-0822922. FSRP has been supported by the Norwegian Research Council through the DecCen and ARCTREC projects.

\section{Supporting Online Material}

www.sciencemag.org

Materials and Methods

Supporting online text

Figs. S1, S2

Tables $1,2,3$ 


\title{
Supporting Online Material for MS\#1198322
}

\section{Catastrophic drought in the Afro-Asian monsoon region during Heinrich Event 1.}

\author{
J. Curt Stager, David B. Ryves, Brian M. Chase, and Francesco S.R. Pausata
}

\section{Materials and Methods}

\section{Lake Victoria cores}

The timing of the first desiccation of Lake Victoria was based on two sediment records. The Damba Channel core was collected from $32 \mathrm{~m}$ depth in Ugandan coastal waters $(S 1)$, and the V95-2P core was collected from a mid-lake station at 66-68 $\mathrm{m}$ water depth (S2). Both cores displayed twinned desiccation surfaces of late Pleistocene age; water content dropped sharply across the uppermost discontinuity and less so in the older, lower break. In the Damba Channel core, mollusk shell lags were also present atop each desiccation surface. Previous estimates of the timing of the two low stands have been limited by a scarcity of radiocarbon dates; a comprehensive review of the subject yielded a range of ca. 18-17 ka for the onset of the first low stand and ca. 16-14 ka for the second one (S3).

\section{Chronology}

Conversions of radiocarbon ages to calendar year ages were undertaken with CALIB version $6.0(S 4)$, using the INTCAL09 dataset (S5), which can yield ages that are slightly different from those that have been used on these cores in the past. Originally, two standard radiocarbon dates were obtained on $30 \mathrm{~cm}$ long subsections of the Damba Channel core above the upper break and from the base of the core $(S 1)$. No plant remains have been obtained in quantities sufficient for AMS dating in this core, but an ancient carbon correction factor of 330 years has been estimated for other sediment records in the Ugandan sector of the lake (S6) and was applied to all sediment and shell dates in the Damba Channel core (Table 1). For this study, two additional AMS dates were obtained on sediments situated between the two desiccation horizons and another one for a sample taken beneath the lower discontinuity (Fig. S1, Table 1). Each centimeter of desiccated sediment between the discontinuities was estimated to represent ca. 35 years, although the overlapping 2-sigma error bars on the two AMS dates did not permit precise determinations (range: $0-185 \mathrm{yr} \mathrm{cm}^{-1}$ ). The $35 \mathrm{yr}$ estimate was approximated from the mean age-depth relationship just above the younger shell lag $\left(21 \mathrm{yr} \mathrm{cm}^{-1}\right)$, assuming that desiccation had compressed the sediments.

Two AMS dates were originally obtained for plant remains collected just above and below the upper desiccation surface in mid-lake core V95-2P (S2); no ancient carbon correction was applied to these dates (Fig. S1, Table 1). Time increments for the interdiscontinuity sediments were estimated to be slightly larger than in the Damba Channel core because the age-depth relationship in this core was $26 \mathrm{yr} \mathrm{cm}^{-1}$; we therefore selected $40 \mathrm{yr} \mathrm{cm}^{-1}$ for the inter-discontinuity sediments in this case. 


\section{Diatom analyses}

Diatom analyses were conducted previously for sediments above the desiccation surfaces in these cores $(S 1, S 7, S 8)$. For this study, additional analyses were also performed on sediments between the two discontinuities; no diatoms were present beneath the lowermost discontinuity in either core, presumably because of subaerial exposure and weathering. The aim of these analyses was to use the presence of diatom assemblages to identify the top of the older sedimentary break, and to reconstruct water conductivity time series that could be used for temporal alignment of the two core sequences. Diatoms were less numerous in these sediments than in the unexposed sediments above the discontinuities, but their quantities and preservation were sufficient for analysis.

Up to 300 valves were identified for each sample, spaced at $1 \mathrm{~cm}$ increments in each core. Diatom taxa indicative of shallow and/or evaporatively concentrated conditions were more common in these deposits than in the sediments above the upper discontinuity, indicating that Lake Victoria lay below its outlet for extended periods. Such taxa in both cores included Cyclotella meneghiniana, $C$. cf. ocellata, Thalassiosira cf. faurii, small Fragilaria spp. sensu lato, and various small Pennales. In total, 43 samples were analyzed from the Damba Channel sequence, and 18 from the V95-2P sequence.

Analog matching of fossil samples was performed within the combined African salinity dataset ( $\mathrm{n}=370$ samples) from the European Diatom Database (S9; EDDI; http://craticula.ncl.ac.uk/Eddi/jsp/), which includes modern samples from northern and eastern Africa $(\mathrm{S} 10)$. As the closest analogs in all cases were from East African sites $(\mathrm{n}=$ 179), the East African subset of the database was used for our conductivity reconstructions. Inferred conductivity $\left(\mu \mathrm{S} \mathrm{cm}^{-1}\right)$ was derived from fossil assemblages $(\%$ data) using a weighted-average transfer function with inverse de-shrinking. The conductivity model performs well when internally validated by leave-one-out jackknifing $\left(r^{2}\right.$ jack $=0.78, \operatorname{RMSEP}=0.41 \log$ units.

Following earlier work which showed that including benthic taxa in fossil data tends to produce over-estimates of surface water lake conductivity $(S 6, S 11)$, we based our conductivity analyses only on euplanktonic taxa. For most samples, there is very good coverage between fossil and modern training sets (average of $70.3 \%$ of fossil data covered for the Damba Channel core, with only 3 samples $<50 \%$, and average of $86.4 \%$ for V95-2P, with 2 samples $<50 \%$ ). Goodness-of-fit was assessed by considering the proportion of fossil data used in each sample for reconstructions, and the minimum dissimilarity coefficient (MinDC) between each fossil sample and the training set. Other studies have suggested that good analogs exist in a training set where minimum dissimilarity coefficients are 100-150 or less $(S 9, S 12)$. No samples exceeded this threshold for MinDC of $>150$. For Damba Channel samples, average MinDC is 91 (range 62-132), and for V95-P2, average MinDC is 104 (range 73-148). Quantitative reconstructions were carried out using the ERNIE (v.1.2) software package within EDDI $(S 9)$. 
Not all of the euplanktonic taxa appeared in the EDDI database, so some substitutions were made on the basis of published data (e.g. S10, S13, S14) and personal experience with African lacustrine diatom ecology. The name Nitzschia cf. gracilis EDDI was assigned to our N. gracilis Hantz., N. acicularis (Kütz.) W. Smith and to the broken tips of long Nitzschia valves. Our Nitzschia vanoyei Choln. was assigned to N. lancettula O.Müll., and Nitzschia palea (Kütz.) W. Smith and similar forms to N. palea agg. EDDI. All forms of Aulacoseira granulata (vars. granulata, angustissima, angustissima fo. curvata, jonensis) were combined into $A$. granulata (agg.) EDDI, and all forms of $A$. agassizii (Osten.) Simonsen assigned to A. agassizii + var. malayensis EDDI.

\section{The age of first desiccation}

The conductivity profiles obtained from the inter-discontinuity interval in both cores displayed a distinctive peak that occurred just above the lower break which, along with the first appearance of diatoms in the record, permitted the two time series to be temporally aligned (inverted scales in Fig. S2B,C). This greatly narrowed the range of possible ages for the resumption of lacustrine sedimentation at each site (shown as red bars in Fig. S2B,C). We used the overlapped portions of these two time spans to represent the most likely time period during which Lake Victoria rose again after its original low stand (dotted red lines in Fig. S2B,C; blue box in Fig. S2A).

A third AMS date on sediment from beneath the lower desiccation surface in the Damba Channel core yielded an age range (17.2-16.8 ka) that was only a few centuries older than that of the AMS date from just above the break (Table 1, Figs. S1B and S2B). This further helped to bracket the onset of the dry period, showing that it was a relatively brief event lasting no more than several centuries, rather than an extended low stand associated with other long-term deglacial or glacial events.

These new data represent strong evidence that the first desiccation of Lake Victoria occurred some time during the 17-16 ka interval, during which Lake Tana also dried out and other tropical African lakes experienced low stands (see main text). The drought that caused the second desiccation of Lake Victoria ca. 15-14 ka was not as widespread, but similar dual low stands did occur elsewhere in equatorial East Africa $(S 15, S 16)$.

\section{Lake Tanganyika core}

Core T97-52V was collected from ca. $40 \mathrm{~m}$ depth atop the Kavala Ridge in the eastcentral portion of Lake Tanganyika and has been described elsewhere (S17). No ancient carbon corrections are considered necessary for late Pleistocene dates in this lake $(S 18)$. Conversion of the 11 radiocarbon dates to calendar years for this study was performed with CALIB version 6.0. Diatom remains in sediments that were deposited during the 10-20 ka time interval were analyzed (at least 300 valves identified per sample) and segregated into planktonic and littoral taxa. High percentages of littoral taxa in offshore sediments in Lake Tanganyika have previously been used to indicate low water stands (S19) during which exposed near-shore deposits are mobilized by wave action and 
redeposited in the deep waters offshore. The maximum percentages of near-shore taxa, including Rhopalodia spp., Staurosirella pinnata, Navicula seminuloides, and miscellaneous Pennales, occurred in the 17-16 ka interval (Fig. 3F).

\section{Supporting text}

\section{Interpretation of regional paleoclimate records}

The coherent signal of intense $\mathrm{H} 1$ aridity in such a large number of widely distributed Afro-Asian records, along with the diversity of paleoclimatic indicators used (including $\delta^{18} \mathrm{O}, \delta^{13} \mathrm{C}, \delta \mathrm{D}$, pollen, diatoms, and varve thicknesses) lends strong support to the conclusions made in this paper. However, not all such records are of equal length, completeness, or clarity, and not all of them come with universally accepted interpretations. We discuss here some of these points further, by region.

\section{African sites}

In addition to the Lake Tanganyika record of East African drought during H1 (Figs. 2D and 3F; S20), a marine record from the Senegal coast (S21) also indicates that the driest conditions of the last $60 \mathrm{kyr}$ occurred in much of the western Sahara-Sahel region, as well.

Climatic conditions at several African sites have been designated "uncertain" on Figure 1 because of unresolved aspects of the content and/or published interpretations of paleoclimate records from those locales. For example, beach deposit records from Lake Chilwa, Malawi (S22), and the sediment record of Lake Masoko, Tanzania (S23-25), have yielded interpretations that are at odds with those from other sites in the region, and discontinuous records and/or alternative explanations for some datasets around the $\mathrm{H} 1$ interval might indicate low stands rather than wet conditions. In addition, high $\delta^{13} \mathrm{C}$ values (indicating an increased $\mathrm{C}_{4}$ grass component in the vegetation) in speleothems from Cold Air Cave, South Africa (Fig. 3H), have previously been taken to represent wetter conditions $(S 26)$. This interpretation, however, has subsequently been shown to be inconsistent with other paleoclimatic proxies from the region (S27). A more parsimonious conclusion, and one that is more consistent with the majority of published interpretations of $\delta^{13} \mathrm{C}$ time series in the tropics, would be that rising $\delta^{13} \mathrm{C}$ reflects an expansion of dry grassland relative to woodlands in response to increased aridity $(S 28$, S29).

\section{Asian sites}

Although most terrestrial paleohydrological records worldwide cover less than $50 \mathrm{kyr}$, several sites in southern Asia do register unusually intense drought during H1. The associated $\delta^{18} \mathrm{O}$ signals in speleothems from monsoonal China, for example, yield the most extreme values of the last $>50 \mathrm{kyr}$ (Fig. 2A,B; S30, S31), with the Sanbao-Hulu Cave composite time series (S32) registering the most extreme $\delta^{18} \mathrm{O}$ excursion of the 130 
kyr record during the $\mathrm{H} 1$ interval. In far western Asia, Lake Van dried out completely when African lakes Victoria and Tana did (S33), and a $50 \mathrm{kyr}$ long speleothem record from NE Turkey registered the most extreme aridity in the entire time series (Fig. 3C: S34). Long speleothem records from Soreq Cave (S35) and Jerusalem West (S36) also indicate unusually severe drought during $\mathrm{H} 1$ although that drying signal was, in both cases, matched by another episode ca. $35 \mathrm{ka}$; those two drought periods, however, were apparently the most intense in at least 130 and $170 \mathrm{kyr}$, respectively. The western sites were strongly influenced by conditions upwind in the Mediterranean Basin; those to the east would primarily represent changes in the Asian monsoon system.

As in the case of equatorial Africa, aridity in the vicinity of equatorial Borneo (Fig. 3C; S37) during $\mathrm{H} 1$ argues against southward drift of the ITCZ alone as an explanation for drought there. Simultaneous wetting at Lynch's Crater, NE Australia (S38) does not necessarily indicate changes within the Asian monsoon system because that region is also strongly influenced by El Niño-Southern Oscillation (ENSO) variability and SSTs in the western tropical Pacific.

\section{South American sites}

In contrast with the Afro-Asian region, most evidence from South America broadly supports the hypothesis of a southward shift of the ITCZ during H1. Aridity during H1 is registered at many sites in the northern neotropics, including the Cariaco Basin (S39), Panama (S40) and Guatemala (S41), although wetter conditions might have begun to develop then along the western coast of Colombia (S42). This possible exception, as well as others noted below, indicate that strict adherence to a conceptual model focused on a southward drift of the ITCZ may risk overlooking potentially significant aspects of variability within the regional climate system.

The geography of tropical South America complicates paleoclimatic interpretations because hydrological conditions in various subregions are not only affected by the ITCZ but also by ENSO, the austral westerlies, orography, and local glacier dynamics. This complexity is evident in the wetter conditions that developed in much of the southern tropical Andes (S42,S43) and in western Peru (S45) during H1, while some evidence from the adjacent southwestern Amazon Basin indicates general aridity (S46). What may be clearer evidence for southward drift or equatorward compression of the ITCZ during $\mathrm{H} 1$ comes from wetting signals in near-equatorial NE Brazil and in SE Brazil (S47, S48), which are linked to a pronounced increase of western tropical Atlantic SSTs in response to reduced MOC (S49). It is important to note concerning our conclusions regarding the causes of $\mathrm{H} 1$ megadroughts in the Old World that this period of warmer western Atlantic SSTs occurred while SSTs surrounding Africa were unusually cool.

Dry conditions also prevailed in parts of southern Brazil $(S 50, S 51)$ while precipitation increased at temperate latitudes farther south beyond the reach of the ITCZ (S52). It therefore appears that the austral westerlies may have moved equatorward over southern South America during H1, possibly restricting migration of the ITCZ there to regions situated relatively close to the equator. 


\section{Supporting figures}
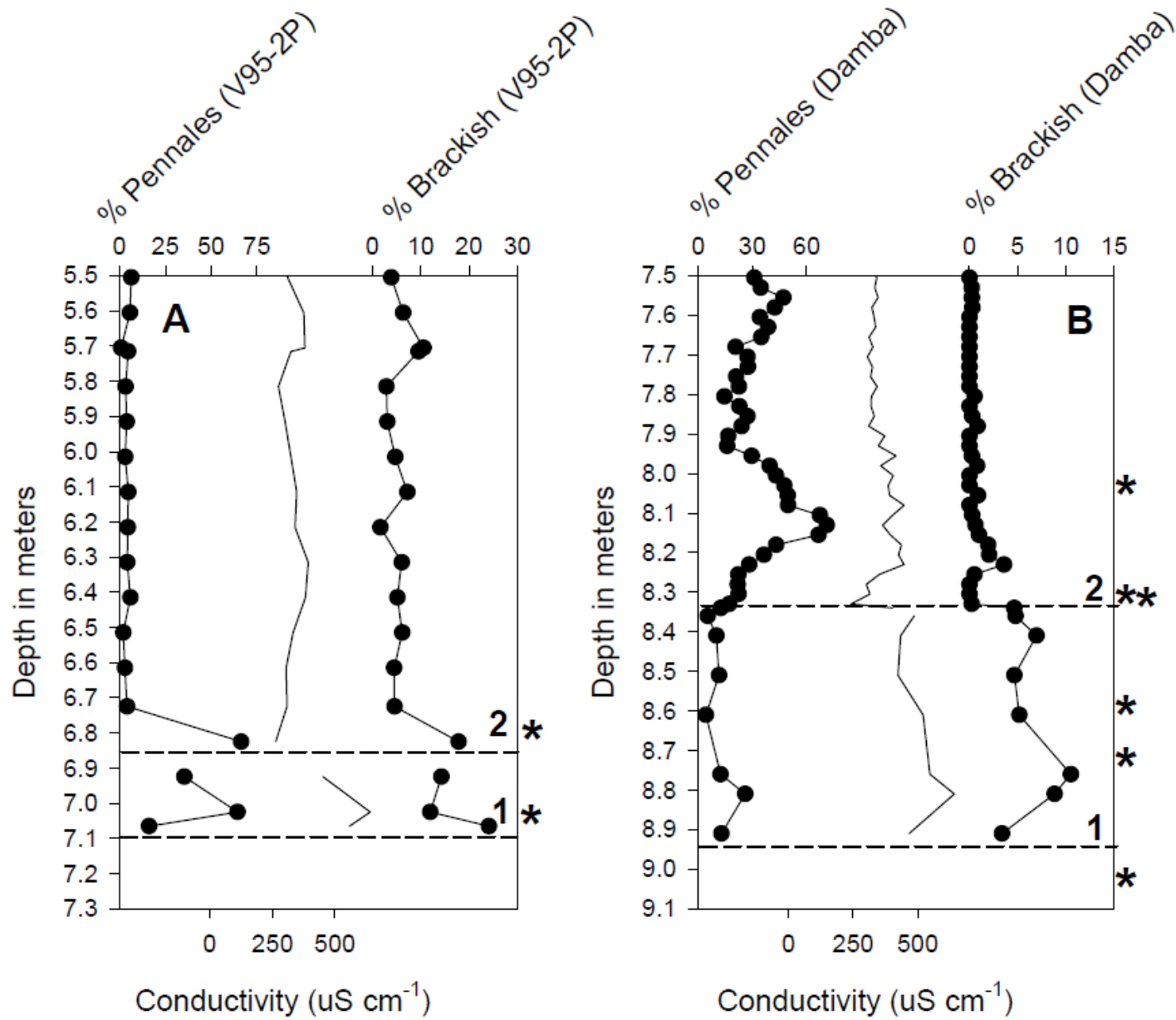

Figure S1. Diatom records used to reconstruct relative levels of Lake Victoria during HS-1 and H1. (A) Mid-lake core V95-2P (S2), (B) Damba Channel core (S1).

Conductivities were inferred from planktonic diatom assemblages as described in Methods. Dashed lines represent two desiccation episodes; line $1=\mathrm{ca} .17-16 \mathrm{ka}$, line $2=$ ca. $14 \mathrm{ka}$. Asterisks indicate positions of radiocarbon dates. 


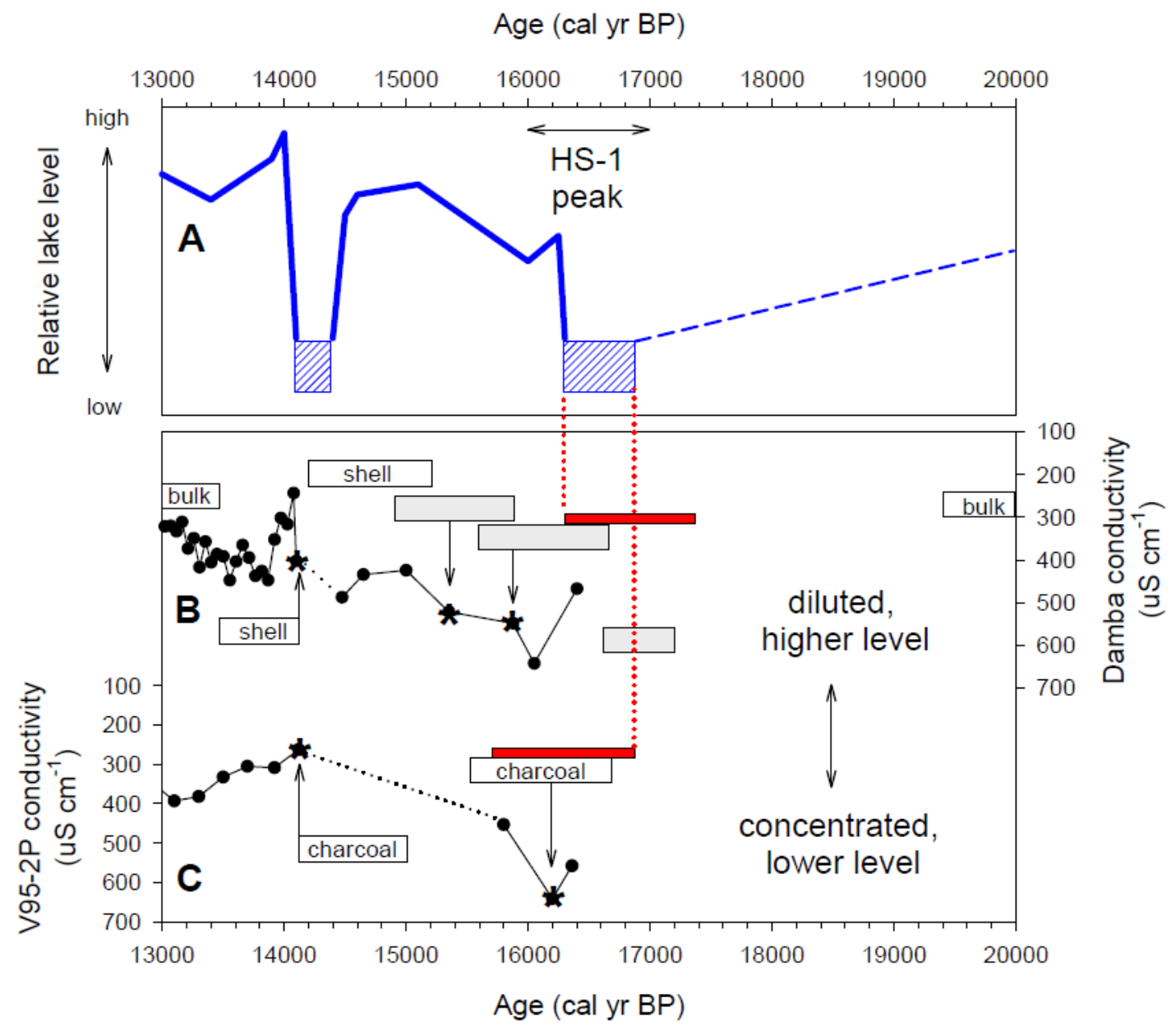

Figure S2. Qualitative reconstruction of Victoria lake level curve between 20 and $13 \mathrm{ka}$. (A) Composite chart of relative lake levels. Hatched boxes indicate likely ranges of time within which the lake dried out. (B and $\mathbf{C}$ ) Inferred conductivity versus time for the Damba Channel and V95-2P cores. Boxes indicate 2-sigma ranges of radiocarbon ages; arrows and asterisks indicate samples chosen for the age models. Grey bars: new AMS dates on bulk sediment obtained for this study. Red bars: most likely dates for recovery from desiccation. Dotted red lines: ages used to constrain the duration of the low stand. Dashed blue line: indicates presence of lake inferred from diatomaceous sediments in offshore core IB3 (S3). 


\section{Supporting tables}

Table 1. Radiocarbon dates from Lake Victoria cores. The sediment and shell dates have 330 years subtracted to compensate for ancient carbon effects (S5). Calendar year conversions were calculated with CALIB 6.0 (S4). Asterisks indicate AMS dates obtained for this study.

\begin{tabular}{|c|c|c|c|c|}
\hline $\begin{array}{c}\text { Sample depth } \\
(\mathrm{m})\end{array}$ & Material & ${ }^{14} \mathrm{C}$ age & $\begin{array}{c}\text { Cal yr range } \\
(\min -\max , 2-\sigma)\end{array}$ & Sample \# \\
\hline \multicolumn{5}{|l|}{ DAMBA } \\
\hline \multicolumn{5}{|l|}{ CORE } \\
\hline 5.39 & $\begin{array}{l}\text { sediment } \\
\text { (bulk) }\end{array}$ & $7580 \pm 80$ & $8201-8542$ & Beta 5455 \\
\hline 8.03 & $\begin{array}{l}\text { sediment } \\
\text { (bulk) }\end{array}$ & $11,380 \pm 120$ & $12,959-13,480$ & Beta 5454 \\
\hline 8.34 & snail shell & $11,970 \pm 130$ & $13,471-14,115$ & AA-33751 \\
\hline 8.34 & snail shell & $12,585 \pm 95$ & $14,216-15,178$ & AA-34698 \\
\hline $8.56-8.61 *$ & sediment & $12,820 \pm 70$ & $14,916-15,871$ & Beta 253782 \\
\hline $8.71^{*}$ & sediment & $13,290 \pm 70$ & $15,588-16,771$ & Beta 253783 \\
\hline $9.01 *$ & sediment & $13,860 \pm 70$ & $16,763-17,156$ & Beta 253784 \\
\hline 9.75 & $\begin{array}{l}\text { sediment } \\
\text { (bulk) }\end{array}$ & $16,980 \pm 300$ & $19,446-21,073$ & Beta 2153 \\
\hline \multicolumn{5}{|l|}{ V95-2P } \\
\hline \multicolumn{5}{|l|}{ CORE } \\
\hline 4.60 & $\begin{array}{l}\text { pollen \& } \\
\text { algae }\end{array}$ & $7850 \pm 50$ & $8522-8973$ & CAMS 22970 \\
\hline 6.81 & charcoal & $12,400 \pm 70$ & $14,086-14,973$ & CAMS 22962 \\
\hline 7.02 & charcoal & $13,240 \pm 80$ & $15,447-16,728$ & \\
\hline
\end{tabular}


Table 2. Diatom data from Lake Victoria cores V95-2P and Damba Channel, and Tanganyika core T97-52V.

\begin{tabular}{ccccc}
\hline Depth (m) & Cal yr BP & $\begin{array}{c}\text { Pennales } \\
(\boldsymbol{\%})\end{array}$ & $\begin{array}{c}\text { Brackish } \\
\text { taxa }(\boldsymbol{\%})\end{array}$ & $\begin{array}{c}\text { Conductivity } \\
\left(\boldsymbol{\mu} \mathbf{S ~ c m}^{-\mathbf{1}}\right)\end{array}$ \\
\hline V95-2 & & & & \\
6.20 & 12900 & 4 & 2 & 341 \\
6.30 & 13100 & 4 & 6 & 393 \\
6.40 & 13300 & 6 & 5 & 382 \\
6.50 & 13500 & 2 & 6 & 333 \\
6.60 & 13700 & 3 & 5 & 305 \\
6.70 & 13920 & 4 & 5 & 309 \\
6.80 & 14120 & 66 & 18 & 263 \\
6.90 & 15800 & 35 & 14 & 453 \\
7.00 & 16200 & 64 & 12 & 641 \\
7.10 & 16360 & 16 & 24 & 558
\end{tabular}

\section{DAMBA}

$\begin{array}{lcccc}7.78 & 12975 & 23 & 0 & 343 \\ 7.81 & 13023 & 15 & 1 & 321 \\ 7.83 & 13070 & 23 & 0 & 320 \\ 7.86 & 13118 & 27 & 0 & 332 \\ 7.88 & 13165 & 24 & 1 & 311 \\ 7.91 & 13213 & 17 & 0 & 373 \\ 7.93 & 13260 & 16 & 0 & 349 \\ 7.96 & 13308 & 30 & 0 & 416 \\ 7.98 & 13355 & 40 & 1 & 357 \\ 8.01 & 13403 & 43 & 0 & 405 \\ 8.03 & 13450 & 48 & 0 & 386 \\ 8.06 & 13502 & 50 & 1 & 391 \\ 8.08 & 13555 & 50 & 0 & 447 \\ 8.11 & 13607 & 67 & 0 & 403 \\ 8.13 & 13660 & 71 & 1 & 365 \\ 8.16 & 13712 & 67 & 1 & 394 \\ 8.18 & 13765 & 43 & 2 & 437 \\ 8.21 & 13817 & 36 & 2 & 426 \\ 8.23 & 13869 & 28 & 4 & 447 \\ 8.26 & 13922 & 22 & 1 & 352 \\ 8.28 & 13974 & 22 & 0 & 301 \\ 8.31 & 14027 & 22 & 0 & 316 \\ 8.33 & 14079 & 17 & 0 & 243 \\ 8.34 & 14100 & 13 & 5 & 402 \\ 8.36 & 14475 & 5 & 5 & 487 \\ 8.41 & 14650 & 10 & 7 & 434 \\ 8.51 & 15000 & 12 & 5 & 424 \\ 8.61 & 15350 & 4 & 5 & 521\end{array}$




$\begin{array}{llccc}8.76 & 15875 & 12 & 11 & 548 \\ 8.81 & 16050 & 26 & 9 & 642 \\ 8.91 & 16400 & 13 & 3 & 467\end{array}$

$\begin{array}{ccc}\text { T97-52V } & & \\ 1.50 & 12855 & 29 \\ 1.60 & 13557 & 34 \\ 1.70 & 14259 & 21 \\ 1.80 & 14961 & 3 \\ 1.90 & 15663 & 49 \\ 2.01 & 16453 & 72 \\ 2.11 & 17462 & 59 \\ 2.21 & 18472 & 36 \\ 2.31 & 19481 & 29 \\ 2.41 & 20491 & 8\end{array}$


Table 3. Paleoclimate records documenting major hydrological disruptions during the 17-16 ka interval (plotted as colored dots in Figure 1).

\begin{tabular}{|c|c|c|c|c|c|c|}
\hline \# & Site name & Latitude & Longitude & Description & Change & Source \\
\hline 1 & $\begin{array}{l}\text { Portugal } \\
\text { (SU81-18) }\end{array}$ & $37^{\circ} 46^{\prime} \mathrm{N}$ & $10^{\circ} 11^{\prime} \mathrm{W}$ & $\begin{array}{l}\text { marine } \\
\text { sediment }\end{array}$ & drier & S53 \\
\hline 2 & $\begin{array}{c}\text { Sofular Cave, } \\
\text { Turkey }\end{array}$ & $41^{\circ} 25^{\prime} \mathrm{N}$ & $31^{\circ} 56^{\prime} \mathrm{E}$ & speleothem & drier & S34 \\
\hline 3 & $\begin{array}{l}\text { Soreq Cave, } \\
\text { Israel }\end{array}$ & $31^{\circ} \mathrm{N}$ & $34^{\circ} \mathrm{E}$ & speleothem & drier & S35 \\
\hline 4 & $\begin{array}{l}\text { Lake Van, } \\
\text { Turkey }\end{array}$ & $38^{\circ} 39^{\prime} \mathrm{N}$ & $42^{\circ} 54^{\prime} \mathrm{E}$ & $\begin{array}{c}\text { lake } \\
\text { sediment }\end{array}$ & desiccated & S33 \\
\hline 5 & $\begin{array}{c}\text { Western } \\
\text { Sahara } \\
\text { (MD03-2705) }\end{array}$ & $18^{\circ} 05^{\prime} \mathrm{N}$ & $21^{\circ} 09^{\prime} \mathrm{W}$ & $\begin{array}{c}\text { marine } \\
\text { sediment }\end{array}$ & drier & S54 \\
\hline 6 & $\begin{array}{l}\text { Senegal coast } \\
\text { (GeoB950805) }\end{array}$ & $15^{\circ} 29^{\prime} \mathrm{N}$ & $17^{\circ} 56^{\prime} \mathrm{W}$ & $\begin{array}{l}\text { marine } \\
\text { sediment }\end{array}$ & $\begin{array}{l}\text { drier } \\
\text { inland }\end{array}$ & S21 \\
\hline 7 & Red Sea & $20^{\circ} \mathrm{N}$ & $39^{\circ} \mathrm{E}$ & $\begin{array}{c}\text { marine } \\
\text { sediment }\end{array}$ & drier & S55 \\
\hline 8 & $\begin{array}{l}\text { Lake Tana, } \\
\text { Ethiopia }\end{array}$ & $12^{\circ} \mathrm{N}$ & $37^{\circ} 15^{\prime} \mathrm{E}$ & $\begin{array}{c}\text { lake } \\
\text { sediment }\end{array}$ & desiccated & S56 \\
\hline 9 & $\begin{array}{l}\text { Socotra Island, } \\
\text { Yemen }\end{array}$ & $12^{\circ} \mathrm{N}$ & $53^{\circ} \mathrm{E}$ & speleothem & drier & S57 \\
\hline 10 & $\begin{array}{c}\text { Lake } \\
\text { Bosumtwi }\end{array}$ & $6^{\circ} 30^{\prime} \mathrm{N}$ & $1^{\circ} 25^{\prime} \mathrm{W}$ & $\begin{array}{c}\text { lake } \\
\text { sediment }\end{array}$ & low stand & S58 \\
\hline 11 & $\begin{array}{c}\text { Lake Barombi } \\
\text { Mbo, } \\
\text { Cameroon }\end{array}$ & $4^{\circ} 40^{\prime} \mathrm{N}$ & $9^{\circ} 24^{\prime} \mathrm{E}$ & $\begin{array}{c}\text { lake } \\
\text { sediment }\end{array}$ & drier & S59 \\
\hline 12 & $\begin{array}{c}\text { Gulf of } \\
\text { Guinea } \\
\text { (MD03-2707) } \\
\text { Niger-Sanaga } \\
\text { watersheds }\end{array}$ & $2^{\circ} 20^{\prime} \mathrm{N}$ & $9^{\circ} 23^{\prime} \mathrm{E}$ & $\begin{array}{c}\text { marine } \\
\text { sediment }\end{array}$ & drier & S60 \\
\hline 13 & Lake Albert, & ca. $1^{\circ} \mathrm{N}$ & ca. $30^{\circ} \mathrm{E}$ & $\begin{array}{c}\text { lake } \\
\text { sediment }\end{array}$ & desiccated & S15 \\
\hline 14 & $\begin{array}{l}\text { Sacred Lake, } \\
\text { Kenya }\end{array}$ & $0^{\circ} 03^{\prime} \mathrm{N}$ & $37^{\circ} 32^{\prime} \mathrm{E}$ & $\begin{array}{c}\text { lake } \\
\text { sediment }\end{array}$ & drier & S16 \\
\hline 15 & $\begin{array}{l}\text { Lake Kivu, } \\
\text { Ruanda,Congo }\end{array}$ & $2^{\circ} \mathrm{S}$ & $29^{\circ} \mathrm{E}$ & $\begin{array}{c}\text { lake } \\
\text { sediment }\end{array}$ & low stand & S61 \\
\hline 16 & $\begin{array}{l}\text { Burundi } \\
\text { Highlands }\end{array}$ & $\begin{array}{l}\text { ca. } 2- \\
4^{\circ} \mathrm{S}\end{array}$ & ca. $30^{\circ} \mathrm{E}$ & $\begin{array}{c}\text { lake } \\
\text { sediment }\end{array}$ & drier & S62 \\
\hline 17 & $\begin{array}{c}\text { Lake Victoria, } \\
\text { Kenya, } \\
\text { Uganda, } \\
\text { Tanzania }\end{array}$ & $\begin{array}{l}\text { ca. } 0- \\
2^{\circ} \mathrm{S}\end{array}$ & $\begin{array}{l}\text { ca. 32- } \\
34^{\circ} \mathrm{E}\end{array}$ & $\begin{array}{c}\text { lake } \\
\text { sediment }\end{array}$ & desiccated & S1-3 \\
\hline
\end{tabular}




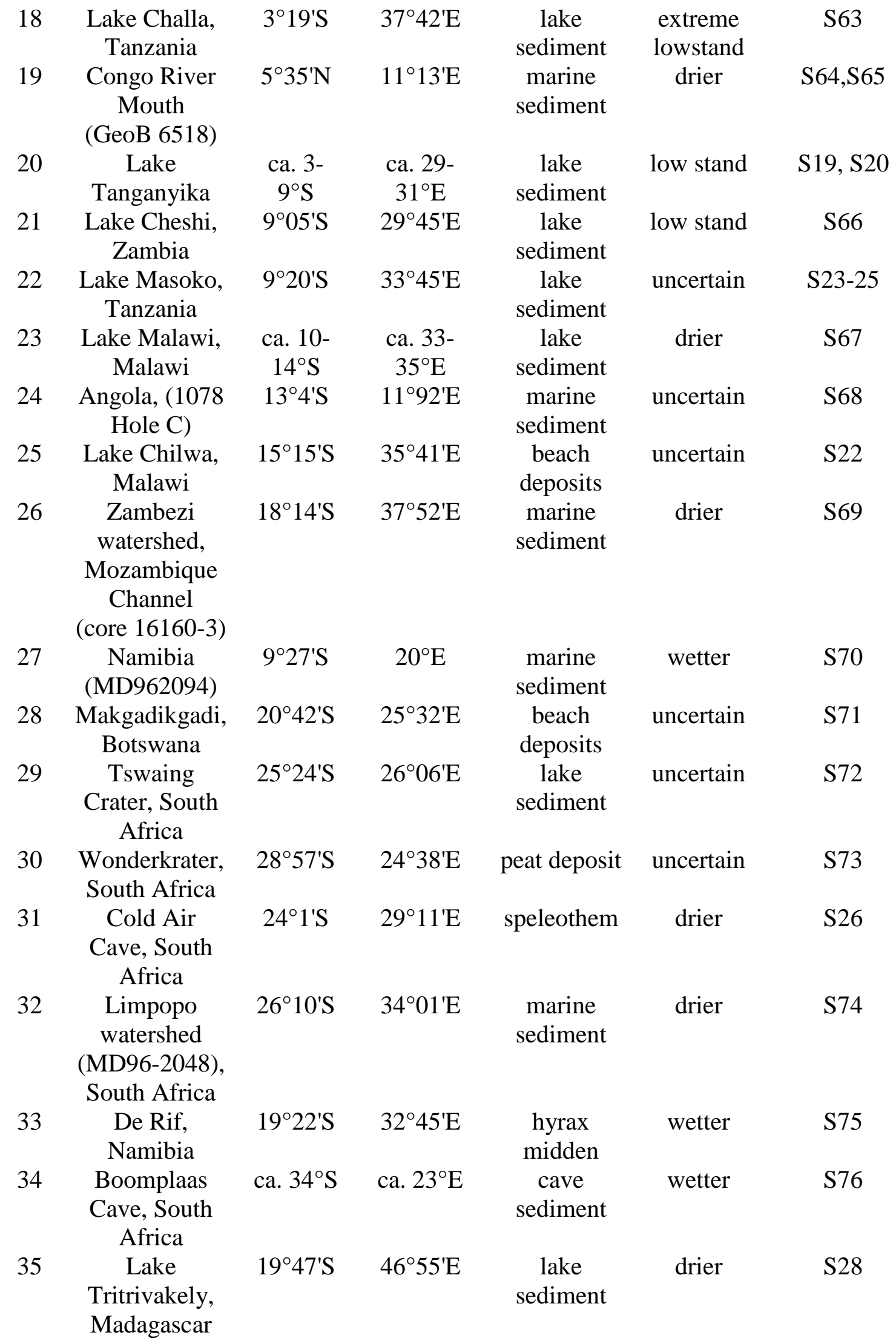




\begin{tabular}{|c|c|c|c|c|c|c|}
\hline 36 & $\begin{array}{c}\text { Arabian Sea } \\
\text { Oxygen } \\
\text { Minimum } \\
\text { Zone } \\
(136 \mathrm{KL})\end{array}$ & $23^{\circ} \mathrm{N}$ & $66^{\circ} \mathrm{E}$ & $\begin{array}{c}\text { marine } \\
\text { sediment }\end{array}$ & drier & S77, S78 \\
\hline 37 & $\begin{array}{l}\text { Indus River } \\
\text { Mouth }\end{array}$ & $\begin{array}{l}23^{\circ} \mathrm{N} \\
\text { core }\end{array}$ & $67^{\circ} \mathrm{E}$ core & $\begin{array}{c}\text { marine } \\
\text { sediment }\end{array}$ & drier & S79 \\
\hline 38 & $\begin{array}{c}\text { Western } \\
\text { Ghats, India } \\
\text { (SK-128A-30) }\end{array}$ & $\begin{array}{c}\text { ca. } 15^{\circ} \mathrm{N} \\
(\text { core } \\
15 \mathrm{~N})\end{array}$ & $\begin{array}{c}\text { ca. } 75^{\circ} \mathrm{E} \\
(\text { core } \\
71^{\circ} \mathrm{N} \\
\left.41^{\prime} \mathrm{E}\right)\end{array}$ & $\begin{array}{c}\text { marine } \\
\text { sediment }\end{array}$ & drier & $\mathrm{S} 80$ \\
\hline 39 & $\begin{array}{l}\text { Lake Naleng, } \\
\text { Mongolia }\end{array}$ & $31^{\circ} 10^{\prime} \mathrm{N}$ & $99^{\circ} 75^{\prime} \mathrm{E}$ & $\begin{array}{c}\text { lake } \\
\text { sediment }\end{array}$ & drier & S81 \\
\hline 40 & $\begin{array}{c}\text { Lanzhou, } \\
\text { China }\end{array}$ & $36^{\circ} \mathrm{N}$ & $104^{\circ} \mathrm{E}$ & peat deposit & drier & S82 \\
\hline 41 & $\begin{array}{l}\text { Midiwan, } \\
\text { China }\end{array}$ & $37^{\circ} 39^{\prime} \mathrm{N}$ & $108^{\circ} 37^{\prime} \mathrm{E}$ & soil profiles & drier & S83 \\
\hline 42 & $\begin{array}{c}\text { Sanbao Cave } \\
\text { China }\end{array}$ & $31^{\circ} 40^{\prime} \mathrm{N}$ & $110^{\circ} 26^{\prime} \mathrm{E}$ & speleothem & drier & S32 \\
\hline 43 & $\begin{array}{c}\text { Hulu Cave, } \\
\text { China }\end{array}$ & $32^{\circ} 30^{\prime} \mathrm{N}$ & $119^{\circ} 10^{\prime} \mathrm{E}$ & speleothem & drier & $\mathrm{S} 30$ \\
\hline 44 & $\begin{array}{c}\text { Dongge Cave, } \\
\text { China }\end{array}$ & $25^{\circ} 17^{\prime} \mathrm{N}$ & $108^{\circ} 5^{\prime} \mathrm{E}$ & speleothem & drier & $\mathrm{S} 31$ \\
\hline 45 & $\begin{array}{l}\text { Andaman Sea } \\
\text { (RC12-344) } \\
\text { (Thailand dry) }\end{array}$ & $12.5^{\circ} \mathrm{N}$ & $96^{\circ} \mathrm{E}$ & $\begin{array}{c}\text { marine } \\
\text { sediment }\end{array}$ & drier & S78 \\
\hline 46 & Borneo & $4^{\circ} \mathrm{N}$ & $114^{\circ} \mathrm{E}$ & speleothem & drier & S37 \\
\hline 47 & $\begin{array}{l}\text { Sunda Islands, } \\
\text { Indonesia } \\
\text { (core G6-4) }\end{array}$ & $10^{\circ} 47^{\prime} \mathrm{S}$ & $118^{\circ} \mathrm{E}$ & $\begin{array}{l}\text { pollen in } \\
\text { marine } \\
\text { sediment }\end{array}$ & drier & S38 \\
\hline 48 & $\begin{array}{l}\text { Lynch's } \\
\text { Crater, }\end{array}$ & $17^{\circ} 37^{\prime} \mathrm{S}$ & $145^{\circ} 70^{\prime} \mathrm{E}$ & $\begin{array}{c}\text { lake } \\
\text { sediment }\end{array}$ & wetter & S84; S38 \\
\hline
\end{tabular}

Australia 


\section{Supporting references and notes}

S1. J. C. Stager, in Proceedings of the. Seventh International Symposium on Living and

Fossil Diatoms, Philadelphia, D. G. Mann, Ed. (Koeltz, Koenigstein, 1984), pp. 455-476.

S2. T. C. Johnson, et al., Science 273, 1091 (1996).

S3. J. C. Stager, P. A. Mayewski, L. D. Meeker, Palaeogeography, Palaeoclimatology, Palaeoecology 183, 169 (2002).

S4. M. Stuiver, P. J. Reimer, Radiocarbon 35, 215 (1993).

S5. P. J. Reimer et al., Radiocarbon 4, 1111 (2009).

S6. J. C. Stager, D. Ryves, B. F. Cumming, L. D. Meeker, J. Beer, Journal of Paleolimnology 33, 243 (2005).

S7. J. C. Stager, T. Johnson, J. Paleolimnol. 23, 373 (2000).

S8. J. C. Stager, B. Cumming, L.D. Meeker, Quaternary Research 47, 81 (1997).

S9. S. Juggins, The European Diatom Database User Guide: Version 1.0. University of Newcastle, Newcastle upon Tyne (2001).

S10. F. Gasse, S., Juggins, L. B. Khelifa, Palaeogeography, Palaeoclimatology, Palaeoecology 117, 31 (1995).

S11. J. C. Stager, C. Cocquyt, R. Bonnefille, C. Weyhenmeyer, N. Bowerman, Quaternary Research 72, 47 (2009).

S12. V. J. Jones, S. Juggins, Freshwater Biology 34, 433 (1995).

S13. F. Gasse, East African diatoms: taxonomy, ecological distribution (J. Cramer, Berlin, 1986).

S14. C. Cocquyt, Diatoms from the northern basin of Lake Tanganyika, (J. Cramer, Berlin, 1998).

S15. K. Beuning, M. R. Talbot, K. A. Kelts, Palaeogeography, Palaeoclimatology, Palaeoecology 136, 259 (1997).

S16. F. A. Street-Perrott, et al., Science 278, 1422 (1997).

S17. C. A. Scholz, et al., Journal of Paleolimnology 30, 139 (2003).

S18. A. A. Felton, et al., Palaeogeography, Palaeoclimatology, Palaeoecology 252, 405 (2007). 
S19. F. Gasse, V. Lédée, M. Massault, J.-C. Fontes, Nature 342, 57 (1989).

S20. J. E. Tierney et al., Science 322, 252 (2008).

S21. S. Mulitza et al., Paleoceanography 23, PA4206 (2008).

S22. D. S. G. Thomas, R. Bailey, P.A. Shaw, J.A. Duncan, J. S. Singarayer, Quaternary Science Reviews 28, 526 (2009).

S23. P. Barker, D. Williamson, F. Gasse, E. Gilbert, Quaternary Science Reviews 60, 368 (2003).

S24. Y. Garcin, et al., Palaeogeography, Palaeoclimatology, Palaeoecology 239, 334 (2006).

S25. F. Gasse, F. Chalié, A. Vincens, M.A.J. Williams, D. Williamson, Quaternary Science Reviews 27, 2316 (2008).

S26. K. Holmgren et al., Quaternary Science Reviews 22, 2311 (2003).

S27. B. M. Chase, M. E. Meadows, A. S. Carr, P. J. Reimer, Quaternary Research 74, 36 (2010).

S28. F. Gasse, E. van Campo, Quaternary Research 49, 299 (1998).

S29. J. A. Lee-Thorp, et al., Geophysical Research Letters 28, 4507 (2001).

S30. Y. J. Wang et al., Science 294, 2345 (2001).

S31. D. Yuan, et al., Science 304, 575 (2004).

S32. Y. Wang et al., Nature 451, 1090 (2008).

S33. G. Landmann, A. Reimer, S. Kempe, Global Biogeochem. Cycles 10, 797 (1996).

S34. D. Fleitmann et al., Geophysical Research Letters 36, L19707, doi:10.1029/2009GL040050 (2008).

S35. M. Bar-Matthews, A. Ayalon, M. Gilmour, A. Matthews, C. J. Hawkesworth, Geochimica et Cosmochimica Acta 67, 3181 (2003).

S36. A. Frumkin, D. C. Ford, H. P. Schwarcz, Global Biogeochemical Cycles 14, 863 (2000).

S37. J. W. Partin, K. M. Cobb, J. F. Adkins, B. Clark, D. P. Fernandez, Nature 449, 452 (2007). 
S38. A. P. Kershaw, S. van der Kaars, P. T. Moss, Marine Geology 201, 81 (2003).

S39. L. C. Peterson, G. H. Haug, K. A. Hughen, U. Röhl, Science 290, 1947 (2000).

S40. M. B. Bush, et al., Ecological Monographs 62, 251 (1992).

S41. D. A. Hodell, et al., Quaternary Science Reviews 27, 1152 (2008).

S42. K. Pahnke, J. P. Sachs, L. Keigwin, A. Timmermann, S.-P. Xie, Paleoceanography 22, PA4214, doi:10.1029/2007PA001468 (2007).

S43. P. Baker, M. Grove, S. Cross, G. Seltzer, S. Fritz, R. Dunbar, Science 291, 640 (2001).

S44. C. Placzek et al., Ann. Missouri Bot. Gard. 96, 386 (2009).

S45. G. Seltzer, D. Rodbell, S. J. Burns, Geology 28, 35 (2000).

S46. F. Mayle, R. Burbridge, T. J. Killeen, Science 290, 2291 (2000).

S47. T. C. Jennerjahn, V. Ittekkot, H. W. Arz, H. Behling, J. Pätzold, G. Wefer, Science 306, 2236 (2004).

S48. F. W. Cruz, Jr., et al. Nature 434, 63 (2005).

S49. S. Weldeab, R. R. Schneider, M. Kolling, Earth and Planetary Science Letters 241, 699 (2006).

S 50. A. Leonhard, M.L. Lorscheitter, Journal of South American Earth Sciences 29, 454 (2010).

S51. M.-P. Ledru et al., Palaeogeography, Palaeoclimatology, Palaeoecology 123, 239 (1996).

S52. D. M. Kröhling, M. Iriondo, Quaternary International 57/58, 149 (1999).

S53. L. Turon, A. M. Lézine, M. Denèfle, Quaternary Research 59, 88 (2003).

S54. E. Jullien, et al., Quaternary Research 68, 379 (2007).

S55. W. G. Deuser, E. T. Degens, in Hot brines and recent heavy metal deposits in the Red Sea, E.T. Degens, D.A. Ross, Eds. (Springer-Verlag, NY, 1969), pp. 336-347.

S56. H. F. Lamb et al., Quaternary Science Reviews 26, 287 (2007).

S57. J. D. Shakun, et al., Earth and Planetary Science Letters 259, 442 (2007). 
S58. J. A. Peck et al., Palaeogeography, Palaeoclimatology, Palaeoecology 215, 37 (2004).

S59. J. Maley, P. Brenac, Review of Palaeobotany and Palynology 99, 157 (1998).

S60. S. Weldeab, D. W. Lea, R. R. Schneider, N. Andersen, Science 316, 1303 (2007).

S61. R. E. Hecky, E. T. Degens, E.T., Woods Hole Oceanographic Institute Technical Report WHOI-73-28 (1973).

S61. R. Bonnefille, F. Chalié, Global and Planetary Change 26, 25 (2000).

S63. D. Verschuren et al., Nature 462, 637 (2009).

S64. J. W. H. Weijers, E. Schefuß, S. Schouten, J. S. S. Damsté, Science 315, 1701 (2007).

S65. E. Schefuss, S. Schouten, R.R. Schneider, Nature 437, 1003 (2005).

S66. J. C. Stager, Quaternary Research 29, 54 (1988).

S67. F. Gasse, P. Barker, T. C. Johnson, in The East African Great Lakes: Limnology, Palaeoclimatology and Biodiversity, E. O. Odada, D. O. Olago, Eds. (Kluwer Academic Publishers, Dordrecht, 2002), pp. 393-414.

S68. L. M. Dupont, H. Behling, J. H. Kim, Clim. Past 4, 107 (2008).

S69. Y. Wang, T. Larsen, N. Andersen, T. Blanz, R. Schneider, Geophysical Research Abstracts 12 (2010).

S70. J.-B.W. Stuut, X. Crosta, K. van der Borg, R. Schneider, Geology 32, 909 (2004).

S71. S. L. Burrough, D. S. G. Thomas, J. S. Singarayer, Earth-Science Reviews 96, 313 (2009).

S72. T. Partridge, in Investigations into the origin, age, and palaeoenvironments of the Pretoria Saltpan, T. C. Partridge, et al., Eds., Council for Geosciences Memoir 85, Geological Survey of South Africa, 1999). pp. 127-142.

S73. L. Scott, K. Holmgren, A. S. Talma, S. Woodborne, J. C. Vogel, South African Journal of Science 99, 484 (2003).

S74. L. Dupont, T. Caley, B. Malaize, J. Girardeau, Geophysical Research Abstracts 12, (2010).

S75. B. M. Chase et al., Geology 39, 19 (2011). 
S76. H. J. Deacon, J. Deacon, A. Scholtz, J. F. Thackeray, J. S. Brink, in Late Cainozoic Palaeoclimates of the Southern Hemisphere, J. C. Vogel, Ed., (Balkema, Rotterdam, 1984) pp. 339-360.

S77. H. Schulz, U. von Rad, H. Erlenkeuser, Nature 393, 54 (1998).

S78. H. Rashid, B. P. Flower, R. Z. Poore, T. M. Quinn, Quaternary Science Reviews 26, 2586 (2007).

S79. U. von Rad et al, Palaeogeography, Palaeoclimatology, Palaeoecology 152, 129 (1999).

S80. C. N. Prabhu, et al., Palaeogeography, Palaeoclimatology, Palaeoecology 214, 309 (2004).

S81. A. Kramer, U. Herzschuh, S. Mischke, C. Zhang, Quaternary Research 73, 324 (2010).

S82. X.-M. Fang, et al., Earth and Planetary Science Letters 168, 219 (1999).

S83. W. Zhou, M. J. Head, X. Lu, Z. An, A. J. T. Jull, D. Donahue, Paleogeography, Paleoclimatology, Paleoecology 152, 163 (1999).

S84. C. S. M. Turney, A. P. Kershaw, S. C. Clemens, N. Branch, P. T. Moss, L. K. Fifield, Nature 428, 306 (2004). 